\title{
First record of the Klunzinger's ponyfish Equulites klunzingeri (Steindachner, 1898) (Leiognathidae) from the coasts of Muscat City at the Sea of Oman
}

Laith A. Jawad ${ }^{1}$, Seishi Kimura ${ }^{2}$ \& Juma M. Al-Mamry ${ }^{1}$

1 Marine Science and Fisheries Centre, Ministry of Fisheries Wealth, P.O. Box 427, postal code 100 Muscat, Sultanate of Oman.

2 Fisheries Research Laboratory, Mie University, 4190-172 Wagu, Shima-cho, Shima, Mie, 517-0703 Japan.

Correspondence

L.A. Jawad

E-mail: laith_jawad@hotmail.com

Received: 2 March 2012

Accepted: 10 July 2012

Published on-line: 17 July 2012

\section{Resumen}

Primera cita de Equulites klunzingeri (Steindachner, 1898) (Leiognathidae) en la costa de Mascate, golfo de Omán

Se capturaron en diciembre de 2010 un total de ciento trece especímenes, larvas y adultos, de Equulites klunzingeri en las costas de la ciudad de Mascate (Omán), golfo de Omán Estas capturas representan la primera cita para el golfo de Omán ampliando su área de distribusión y sugiere la existencia de una población estable de la especie.

Palabras clave: Golfo de Omán, Equulites kluncingeri, Omán.

\begin{abstract}
A total of one hundred and thirteen adult and juvenile specimens of the Klunzinger's ponyfish, Equulites klunzingeri (Steindachner, 1898) were captured by seine net from coasts of Muscat City at the Sea of Oman in December 2010. This record is considered the first for the Sea of Oman and may suggest an establishment of a selfsustained population of the species.
\end{abstract}

Key words: Sea of Oman, First record, Equulites klunzingeri, Oman.

\section{Introduction}

The general morphological characters of the members of the family Leiognathidae are silver coloration, small sized body (usually $300 \mathrm{~mm} \mathrm{SL}$ ) laterally compressed. They are known as ponyfishes or slipmouths due to have highly protractible mouth, which protract either dorsally, rostrally, or ventrorostrally (Kimura et al., 2003, 2005). Family Leiognathidae has been reviewed by James (1978), Kühlmorgen-Hille (1974), James (1984), Jones (1985), Shen and Lin (1985), and Woodland et al. (2001), and came to consist 3 genera and more than 25 species, since then the taxonomy of ponyfishes has changed significantly. Recently, many taxonomic changes have taken place including the discovery of novel taxa and the total number of species reached to approximately 47 species belonging to 9 genera (Chakrabarty et al., 2010).

Recently, the genus Equulites Fowler, 1904 has been resurrected within the family Leiognathidae to solve its taxonomic dilemma (Kimura et al., 2008; Chakrabarty \& Sparks, 2008). It is originally described by Folwer (1904) as a subgenus of Leiognathus in order to accommodate his newly described species Leiognathus vermiculatus Fowler, 1904 and L. virgatus Fowler, 1904. Latter, this subgenus has been elevated to the generic level by Kimura et al. (2008). Within the entire geographic range of the family Leiognathidae, the members of this genus have been widely distributed. All the members of the genus Equulites are sexually dimorphic with respect to light-organ 
volume and shape (Chakrabarty \& Sparks, 2008).

The members of the genus Equulites can be distinguished from the members of other genera of Leiognathidae in having following combination of characters: mouth protruding forward, an expansive translucent lateral stripe, triangular, cornucopia-shaped or trapezoidal patch on the flank in males, pigmentation pattern on the dorsal flank comprising speckles, and vermiculate markings or broad oblong markings that occasionally form open circular patterns.

The genus Equulites comprises nine species: E. absconditus Chakrabarty \& Sparks, 2010 from Northwest Pacific, Taiwan (Chakrabarty et al., 2010); E. antongil (Sparks, 2006) from Western Indian Ocean, Madagascar (Eschmeyer, 2007); $E$. elongatus (Günther, 1874) from Indo-West Pacific: east coast of Africa and off southwest India, eastwards to the Philippines, north to Japan, south to Australia (Froese et al., 2010); E. klunzingeri (Steindachner, 1898) from Red Sea and Mediterranean Sea from Tunisia eastwards. Immigrant from the Red Sea through the Suez Canal were recorded (Por, 1978; Roux, 1986; Bilecenoglu et al., 2002; Golani et al., 2002), E. laterofenestra (Sparks \& Chakrabarty, 2007) from Western Pacific, Philippines (Sparks \& Chakrabarty, 2007); Equulites leuciscus (Günther, 1860) from Indo-West Pacific, East Africa to northern Australia and New Caledonia (Froese et al., 2010); E. moretoniensis (Ogilby, 1912) from Western Pacific: northwestern Australia and Papua New Guinea (Gloerfelt-Tarp et al., 1984; Kailola, 1987); E. rivulatus (Temminck \& Schlegel, 1845) from Western Pacific:, southern Japan, East China Sea and the South China Sea and E. stercorarius (Evermann \& Seale, 1907) from Indo-West Pacific: Indonesia, Philippines, New Guinea, and Guam. Recently, this species has been recorded from Tonga (Randall et al., 2003).

\section{Material and methods}

During December 2010, 113 specimens of $E$. klunzingeri (65-104 mm TL) (Fig. 1) were captured by seine net from coasts of Muscat City at the Sea of Oman $\left(23^{\circ} 35^{\prime} 46.93^{\prime \prime} N\right.$; 58 $58^{\circ} 43^{\prime} 08.47^{\prime \prime}$ E) (Fig. 2). The specimens were deposited in the fish collection of the Marine Science and Fisheries Centre, Ministry of Fisheries Wealth, Muscat, Oman, catalogue numbers OMMSFC 1077. Morphometric and meristic details are given in tables 1 and 2 .

Our record of E. klunzingeri is based on 113 specimens collected from Muscat City coasts of the Sea of Oman. So far, the present record of $E$. klunzingeri in the Sea of Oman is considered the eastmost extension of this species.

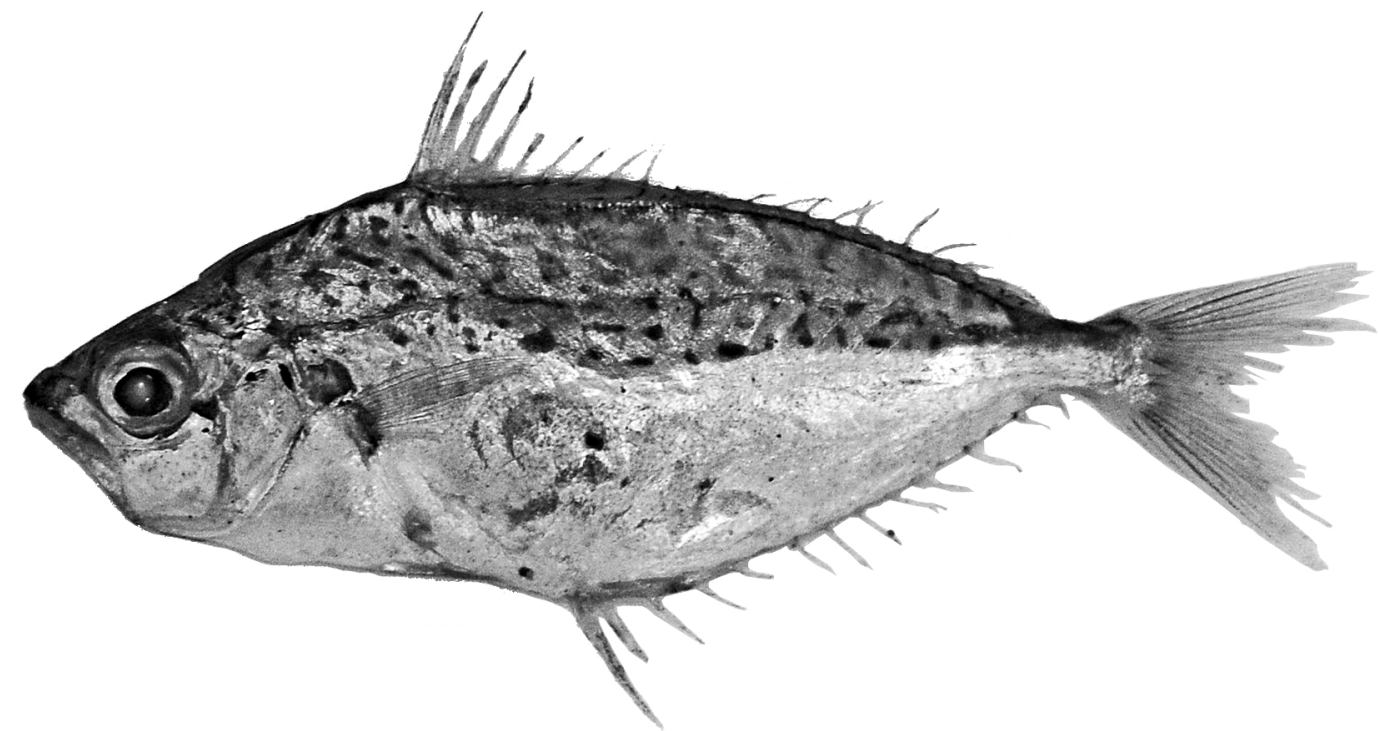

Figura 1. E. klunzingeri, OMMSFC 1077, de $67 \mathrm{~mm}$ de longitud estándar, capturado con red de cerco profunda en las costas de la ciudad de Mascate, golfo de Omán, en abril de 2011.

Figure1. E. klunzingeri, OMMSFC 1077, $67 \mathrm{~mm}$ Standard length, captured by deep seine net from coasts of Muscat City at the Sea of Oman, 


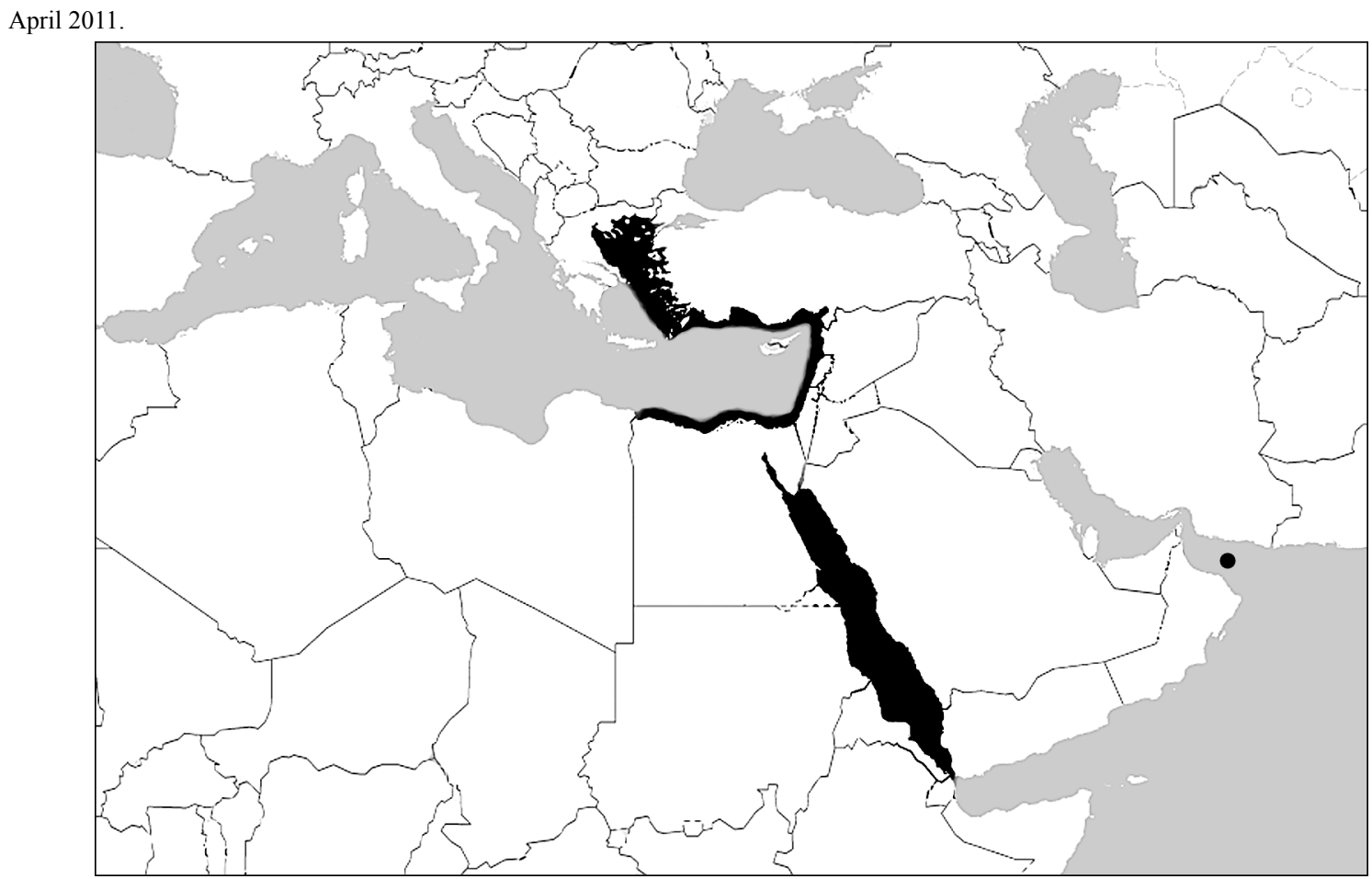

Figura 2. Distribución conocida de E. kunzingeri.

Figure 2. Map showing world distribution of E.klunzingeri.

\section{Results and description}

E. klunzingeri from the Sea of Oman has the following characteristics: body oblong, fairly compressed; distinctive protrucible mouth directed downward when protracted; straight profile in forehead and snout region or just barely weakly concave; posterior main part of body from the nape fairly convex; top of head with bony ridges; villiform teeth on jaw; absence of palatine and vomerine teeth; body almost fully covered with small scales; dorsal fin originating just posterior to a vertical though the base of pelvic-fin spine, with somewhat elongated second dorsal-fin spine (tip reaching to the mid-point of base of soft part of dorsal fin when appressed); scaly sheath covering soft parts of dorsal and anal fins. The specimens have the following coloration: body silverygrey with dark patches unevenly distributed over dorsal part; iris golden; belly white; dorsal-fin base black. The important character of the species is the pigmentation on dorsolateral body. The species has short oblique black lines on dorsolateral body above lateral line and black blotches and short vertical lines on upper lateral body just below the lateral line. E. klunzingeri has a demersal coastal marine life in the tropical seas around the world to 70 meters (Froese \& Pauly, 2010). It inhabits sandy or muddy bottom. This species feeds on bottom invertebrates which are captured with its protrusible mouth. It reproduces in the summer months and egg and larvae are planktonic (Roux, 1986).Due its small size, this species usually is caught by trawl.

E. klunzingeri was originally described from the Suez Bay, Red Sea by Steindachner (1898). Through the Suez Canal, E. klunzingeri immigrated to the Mediterranean Sea where it has been recorded from Tunisia eastward (Roux, 1986). This species is among the Red Sea fish species that are widely distributed (Gücü, et al., 1993). In the Meditrerranean Sea, it has been recorded from several places, Ben-Tuvia (1978) reported $E$. klunzingeri from the southern coasts of Sicily, Avsar et al. (1988) recorded it from the Turkish waters of the Mediterranean Sea, Ben-Tuvia (1966) found one specimen of this species from the vicinity of Lampedusa Island near the eastern coast of Tunisia and Dulčić \& Pallaoro (2002) have caught one specimen from Adriatic Sea. For 
the species in question, no southward or eastward extensions from its original distribution in the Red Sea have been on record so far.

E. elongatus is the only other member of the genus Equulites found in Omani waters, thus it is important to mention how E. klunzingeri differs from E. elongatus. It differs in having color pattern of dark markings dorsolaterally on body; compressed, oval body shape; and mouth very protrudinge.

Although E. klunzingeri is very similar to $E$. leuciscus in general body shape and pattern of dark markings on dorsolateral body surface, the former could be distinguished from the latter by having more obvious and complicated dark markings and second anal-fin spine never elongated.

\begin{tabular}{|l|c|c|}
\hline \multicolumn{1}{|c|}{$\begin{array}{c}\text { Morphometric } \\
\text { characters }\end{array}$} & $\begin{array}{c}\text { Present } \\
\text { study }\end{array}$ & $\begin{array}{c}\text { Dulčić and } \\
\text { Pallaoro } \\
\text { (2002) }\end{array}$ \\
\hline Total length (TL) & $\begin{array}{c}65-104 \\
(79.9)\end{array}$ & 85 \\
\hline Fork length (FL) & $\begin{array}{c}58-69 \\
(77.8)\end{array}$ & - \\
\hline \% in TL & $\begin{array}{c}85.7-95.2 \\
(90.75)\end{array}$ & - \\
\hline $\begin{array}{l}\text { Standard length } \\
\text { (SL) }\end{array}$ & $\begin{array}{c}51-83 \\
(68.1)\end{array}$ & 69.1 \\
\hline \% in TL & $\begin{array}{c}77.8-84.8 \\
(79.6)\end{array}$ & 81.3 \\
\hline Head length (HL) & $\begin{array}{c}14-24 \\
(19.1)\end{array}$ & 19.9 \\
\hline \% in SL & $\begin{array}{c}22.1-29.5 \\
(27.2)\end{array}$ & 28.8 \\
\hline $\begin{array}{l}4-8 \\
\text { (Preorbital O.L.) }\end{array}$ & $\begin{array}{c}45.8) \\
(5.8)\end{array}$ & 7.1 \\
\hline \% in HL & $\begin{array}{c}27.8-35.0 \\
(30.4)\end{array}$ & 35.7 \\
\hline Postorbital length \\
(Post. O.L.) & $\begin{array}{c}5-9 \\
(6.4)\end{array}$ & $\begin{array}{c}71.4-93.9 \\
(89.0)\end{array}$ \\
\hline \% in HL & $\begin{array}{c}13-26 \\
(20.7)\end{array}$ \\
\hline Eye diameter \\
(ED)
\end{tabular}

\begin{tabular}{|l|c|c|}
\hline Morphometric characters & $\begin{array}{c}\text { Present } \\
\text { study }\end{array}$ & $\begin{array}{c}\text { Dulčić and } \\
\text { Pallaoro } \\
\text { (2002) }\end{array}$ \\
\hline \% in SL & $\begin{array}{c}24.7-31.8 \\
(29.7)\end{array}$ & 30.1 \\
\hline $\begin{array}{l}\text { Pectoral fin length } \\
\text { (P.F.L.) }\end{array}$ & $\begin{array}{c}10-15 \\
(12.4)\end{array}$ & 12.7 \\
\hline \% in SL & $\begin{array}{c}16.5-19.7 \\
(18.2)\end{array}$ & 18.4 \\
\hline $\begin{array}{l}\text { Preanal fin length } \\
\text { (Pre. A.F.L.) }\end{array}$ & $\begin{array}{c}29-46 \\
(35.6)\end{array}$ & 35.1 \\
\hline \% in SL & $\begin{array}{c}40.0-54.7 \\
(50.0)\end{array}$ & 50.8 \\
\hline $\begin{array}{l}5 \text { ostanal fin length } \\
\text { (Post. A.F.L.) }\end{array}$ & $\begin{array}{c}54-79 \\
(63.9)\end{array}$ & - \\
\hline \% in SL & $\begin{array}{c}71.4-95.2 \\
(88.8)\end{array}$ & - \\
\hline $\begin{array}{l}\text { Preanus length } \\
\text { (Pre. An. L.) }\end{array}$ & $\begin{array}{c}22-34 \\
(27.0)\end{array}$ & - \\
\hline \% in SL & $\begin{array}{c}36.5-44.3 \\
(39.3)\end{array}$ & - \\
\hline $\begin{array}{l}\text { Anal fin length } \\
\text { (An. F.L.) }\end{array}$ & $\begin{array}{c}25-37 \\
(30.7)\end{array}$ & - \\
\hline \% in SL & $\begin{array}{c}39.8-45.0 \\
(47.0)\end{array}$ & - \\
\hline $\begin{array}{l}\text { Caudal peduncle length } \\
\text { (C.P.L.) }\end{array}$ & $\begin{array}{c}3-6 \\
(4.0)\end{array}$ & - \\
\hline \% in SL & $\begin{array}{c}5.1-7.3 \\
(6.0)\end{array}$ & - \\
\hline $\begin{array}{l}14-27 \\
(19.7)\end{array}$ & $\begin{array}{c}23.6-32.8 \\
(29.6)\end{array}$ & - \\
\hline \%.D.O.) & $\begin{array}{c}22-33 \\
(26.7)\end{array}$ & 27.1 \\
\hline $\begin{array}{l}\text { Body depth at the body } \\
\text { midline } \\
\text { (B.D.M.L.) }\end{array}$ & $\begin{array}{c}29.9-40.3 \\
(37.6)\end{array}$ & 39.2 \\
\hline \% in SL & \multicolumn{2}{|c|}{-} \\
\hline
\end{tabular}

Tabla 1. Medidas morfométricas de Equilites kluzingeri en mm. Media entre paréntesis. Ejemplares de este estudio n=113 Table 1. Morphometric measures of Equilites kluzingeri in mm. Mean value in parentheses. Present study n=113. 


\begin{tabular}{|l|c|c|}
\hline \multicolumn{1}{|c|}{$\begin{array}{c}\text { Meristic } \\
\text { characters }\end{array}$} & $\begin{array}{c}\text { Present } \\
\text { study }\end{array}$ & $\begin{array}{c}\text { Dulčić and } \\
\text { Pallaoro (2002) }\end{array}$ \\
\hline Dorsal fin spines & 8 & 8 \\
\hline Dorsal fin rays & 16 & 15 \\
\hline Pectoral fin rays & 19 & 16 \\
\hline Pelvic fin spines & 1 & 1 \\
\hline Pelvic fin rays & 5 & 5 \\
\hline Anal fin spines & 3 & 3 \\
\hline Anal fin rays & 16 & 15 \\
\hline
\end{tabular}

global change, a recent natural colonization along the northern coast of the Indian Ocean has been taken place; (iii) the Sea of Oman is the only way leading to the Persian Gulf which is considered as one of the busiest waterways in the world and ballast water from ships is a possible. The capture during this study should not be regarded as accidental as 113 individuals were collected which indicate the presence of a self-sustaining population of this species in the Sea of Oman. Thus, it is possible to decide that E. klunzingeri is a natural element of the ichthyofauna of the Sea of Oman.

Tabla 2. Características merísticas de Equilites kluzingeri. n=113 Table 2. Meristic characters of Equilites kluzingeri. $\mathrm{n}=113$.

the range of total length of the specimens obtained in the present study for E. klunzingeri is smaller (65-104 mm) (Table 1) than those obtained by Steindachner (1898) in his original description of the species $(104 \mathrm{~mm})$. Golani et al. (2002) and Golani et al. (2006) have mentioned a range of 40-80 mm with maximum total length of $110 \mathrm{~mm}$. On the other hand, the specimen of Dulčić \& Pallaoro (2002) was $85 \mathrm{~mm}$ in total length. It is obvious that the lower limit of the total length of our specimens is the lower total length ever recorded for this species and the upper limit is within the range given by other authors.

Comparing our specimens of E. klunzingeri with the single specimen obtained by Dulčić \& Pallaoro (2002), it is obvious that all body measurements of the specimen of Dulčić \& Pallaoro (2002) fall within the range obtained in the present study for those proportions. The preorbital length of the specimen of Dulčić \& Pallaoro (2002) lies near the upper range given for this character by the present study. However, postorbital length, eye diameter, predorsal length, body depth and pectoral fin length of Dulčić \& Pallaoro (2002) specimen fall on the lower limit of the range obtained for these characters in the present study (Table 1).

There are several factors that might stop recording E. klunzingeri from the Sea of Oman previously. Among these we can reside on (i) the lack of sampling in the area prevents the regular detection of this species in the Sea of Oman although it has been present since the postglacial re colonization of the Sea of Oman by marine fish and has been overlooked in the past; (ii) due to

\section{Acknowledgements}

We would also like to thank the Ministry of Fisheries Wealth, Marine Science and Fisheries Centre, Ministry of Fisheries Wealth and the directorate of Agriculture and Fisheries Developmental Fund for giving us the opportunity to work on the fish samples within the qualitative and quantitative distribution of marine organisms in Sultanate of Oman and to provide the appropriate financial support. We should thank Raymond Coory (Te Papa Tongarewa, Wellington, New Zealand) for the technical assistant in producing images.

\section{References}

Avsar D, Bingel F \& Unsal M. 1988 Application of Mahlanobis distance function for morphometric separation of silverbelly (Leiognathus klunzingeri) stocks in the Gulf of Marsin. Acta Adriatica, 29: 153-160.

Ben-Tuvia A. 1966. Red Sea recently found in the Mediterranean. Copeia, 2: 254-275.

Ben-TuviaA.1978. Immigration of fishes through the Suez Canal. Fishery Bulletin, 76: 249-255.

Bilecenoglu M, Taskavak E Mater S \& Kaya M. 2002. Checklist of the marine fishes of Turkey. Zootaxa, 113: 1-194.

Chakrabarty P \& Sparks JS. 2008. Diagnoses for Leiognathus Lacepède 1802, Equula Cuvier 1815, Equulites Fowler 1904, Eubleekeria Fowler 1904, and a New Ponyfish Genus (Teleostei: Leiognathidae). American Museum Novitate, 3623: 1-11.

Chakrabarty P \& Sparks JS. 2010. Taxonomic review of the ponyfishes (Perciformes: Leiognathidae) of Taiwan. Marine Biodiversity Records, 40: 107-121

Chakrabarty P, Chu J, Nahar L \& Sparks JS. 2010. Geometric morphometrics uncovers a new species of ponyfish (Teleostei: Leiognathidae: Equulites), with comments on the taxonomic status of Equula berbis Valenciennes. Zootaxa, 2427: 15-24. 
Dulĉić J \& Pallaoro A. 2002. First record of the lessepsian migrant Leiognathus kluzingeri (Pisces: Leiognathidae) from the Adriatic Sea. Journal of the Marine Biological Association of United Kingdom, 82: 523-524.

Eschemeyer WN. (ed.) 2007. Catalog of fishes. Updated database version of June 2007. Catalog databases as made available to FishBase in June 2007.

Fowler HW. 1904. A collection of fishes from Sumatra. Journal of the Academy of Natural Sciences of Philadelphia (Ser 2), 12: 495-560.

Froese R \& Pauly D. 2010. Fish Base. World Wide Web electronic publication. Version (12/2010) www.fishbase.org.

Gloerfelt-Tarp T \& Kailola PJ. 1984. Trawled fishes of southern Indonesia and northwestern Australia. Australian Development Assistance Bureau, Australia, Directorate General of Fishes, Indonesia, and German Agency for Technical Cooperation, Federal Republic of Germany. 407 p.

Golani D, Orsi-Relini L, Massuti E \& Quignard JP. 2002. CIESM Atlas of Exotic species in the Mediterranean Volume 1: Fishes. F. Briand (Ed), Monaco. CIESM Publishers, $256 \mathrm{pp}$.

Gücü AC, Bingel F \& Uysal N. 1993. Distribution and occurrence of Red Sea fish at the Turkish Mediterranean coast-Northern Cilician Basin. Acta Adriatica, 34: 103-113.

James PSBR. 1978. A systematic review of the fishes of the family Leiognathidae. Journal of the Marine Biological Association of India, 17: 138-172

James PSBR. 1984. Leiognathidae. In: FAO species identification sheets for fishery purposes, W. Fischer \& G. Bianchi (Eds), Western Indian Ocean (Fishing Area 51), vol 2. FAO, Rome.

Jones G.1985. Revision of the Australian species of the fish family Leiognathidae. Australian Marine and Freshwater Researchs, 36: 559-613.

Kailila PJ. 1987. The fishes of Papua New Guinea: a revised and annotated checklist. Vol. II Scorpaenidae to Callionymidae. Research Bulletin No. 41, Research Section, Dept. of Fisheries and Marine Resources, Papua New Guinea.

Kimura S, Dunlap PV, Peristiwady T \& Lavilla-Pitogo CR. 2003. The Leiogathus aureus complex (Perciformes: Leiognathidae) with the description of a new species. Ichthyological Research, 50: 221-232.

Kimura S, Ito T, Peristiwady T, Iwatsuki YT, Yoshino T \& Dunlap PV. 2005. The Leiognathus splendens complex (Perciformes: Leiognathidae) with the descrip- tion of a new species, Leiognathus kupanensis Kimura and Peristiwady. Ichthyological Research, 52: 275-291.

Kimura S, Motomura H \& Iwatsuki Y. 2008. Equulites Fowler 1904, a senior synonym of Photoplagios Sparks, Dunlap, and Smith 2005 (Perciformes: Leiognathidae). Ichthyological Research, 55, 204-205

Kühlmorgen-Hille G. 1974. Leiognathidae. In: FAO species identification sheets for fishery purposes. Eastern Indian Ocean (Fishing Area 57) and Western Central Pacific (Fishing Area 71), W.Fischer \& P.J.P.Whitehead (Eds), vol 2. FAO, Rome.

Pord FD. 1978. Lessepsian Migration: the influx of Red Sea Biota into the Mediterranean by Way of the Suez Canal. p.228. Springer-Verlag, Berlin, Heidelberg, New York.

Roux C. 1986. Leiognathidae. p. 856-857. In P.J.P. Whitehead, M.-L. Bauchot, J.-C. Hureau, J. Nielsen and E. Tortonese (eds.) Fishes of the north-eastern Atlantic and the Mediterranean. UNESCO, Paris. Vol. 2.

Randall JE, Williams JT, Smith DG, Kulbicki M, Tham GM, Labrose P, Kronen M, Clua E \& Mann BS. 2003. Checklist of the shore and epipelagic fishes of Tonga. Atoll Research Bulletin, 34: 497-508.

Shen SC \& Lin WW. 1985. Study on the leiognathid fishes of Taiwan. Bulletin of the Institute of Zoology, Academia Sinica, 24: 125-138.

Sparks JS \& Chakrabarty P. 2007. A new species of ponyfish (Teleostei: Leiognathidae: Photoplagios) from the Philippines. Copeia, 3: 622-629.

Sparks JS, Dunlap PV \& Smith W. 2005. Evolution and diversification of a sexually dimorphic luminescent system in ponyfishes (Teleostei: Leiognathidae), including diagnoses for two new genera. Cladistics, 21: 305-327.

Steindachner F. 1898. Uber einige neue Fischarten aus dem rothen Meere, gesammelt wahrend der I. und II. osterreichischen Expedition nach dem rothen Meere in den Jahren 1895-1896 und 1897-1898. Sitzungsberichte der Kaiserlichen Akademie der Wissenschaften. Mathematisch-Naturwissenschaftliche Classe, 107, 780-788.

Woodland DJ, Premchaoen S \& Cabanban AS. 2001. Leiognathidae. In: FAO species identification guide for fishery purposes, The living marine resources of the Western Central Pacific, K. E. Carpenter \& V.H. Niem (Eds), vol. 5, bony fishes part 3 (Menidae to Pomacentridae). FAO, Rome, pp 2792-2823. 